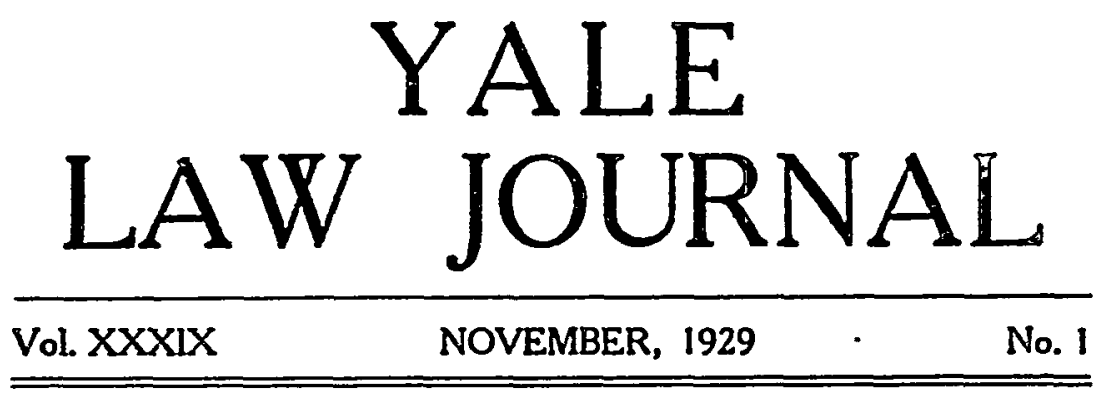

\title{
THE CASE METHOD IN CANADA AND THE POSSIBILITIES OF ITS ADAPTATION TO THE CIVIL LAW
}

\section{EDOUARD LAMBERT AND MIAX J. WASSERIAAN}

Two recent works, ${ }^{1}$ while quite different in their nature and their purpose, are particularly interesting to the student of comparative law. The first is a Canadian casebook-a casebook of high rank-which has been written for the teaching of the law of the sale of goods. The second is a part of a pedagogical investigation of the function and work of the present-day law schools of North America. But they commend themselves simultaneously to the attention of the student of comparative law because of the information which they give on the recent progress of the case method in the Canadian Provinces of common law, as well as on the limited applicability of the case method and the European method of legal education, which latter consists in the synthetic exposition of the principles of law by courses of oral lectures on the ensemble of the system of law.

The comparison of Falconbridge's casebook with the most renowned casebook on the same topic in use in the United States -Williston's Cases on the Sale of Goods-shows at the first glance that legal education by means of the study of cases may be extended and, above all, employed in widely differing fashions. This comparison brings out that, in order to acclimate itself to other countries of common law than the United States and, a fortiori, in order to penetrate into the countries of civil law,

\footnotetext{
1 Falconbride, a Selection of Cases on the Sale of Goods (1927); Repd, Present-Day Law Schools iN the United States aNd CaNada (1928), constituting Bulletin 21 of the Carnegie Foundation for the Advancement of Teaching, Part IV.
} 
the teaching of law by the discussion of cases must, notably, soften the rigidity, the spirit of exclusiveness, and the pugnacious humor which the disciples of Dean Christopher Columbus Langdell gave it.

One cannot say that Langdell's discovery was prolem sine matre creatam. It seeks to imitate, by rendering them more tractable and by disciplining them, the very laws of legal education through practice. It finds its first precedents in the instinctive efforts for self-education of the apprentices at law who, at the turning point from the 13th to the 14th century, followed and discussed among themselves the pleadings in the "crib" of Westminster Hall, and whose notes formed the first outlines of the Year Books. Above all it connects itself with the method of collective education of the old Inns of Court which, in creating a demand for a more coherent production-and above all for a production of larger diffusion - of the old livres de terme, seems to have given the Year Books their final aspect. ${ }^{2}$ In adapting itself to present-day conditions, Langdell's system of legal education has become different from these medieval models in two ways : in the substitution of the study of substantive law for the study of procedure, which has been relegated to the role of adjective law; and in the use of classbooks in the form of collections of select cases, which are handier and of greater educational value than the Year Books or their successors. But the essence itself of the method has not changed; it remains a purely inductive method, or more exactly a purely empirical method. Harvard's infiuence caused it to spread through the immense majority of the law schools of the United States. It is therefore permissible to call it the American case method.

The American case method aims to teach law to future practitioners just as one teaches children how to swim, by throwing them immediately into the water. As soon as the student arrives at school he is placed before legal problems as they appear before the courts, in the form of cases of law submitted to the judges. This method gives him practice in deducing, by means of his own reflection, the principles involved in each case and the raisons d'etre of the conciliation reached by the courts between the principles in conflict. It endeavors to prepare the student directly for the work which he will need to do upon his graduation from the school, and also in the form in which this work will present itself to him, the form of replies to questions of consultation or judgment. Without doubt the general principles of law do not reveal themselves to him with the same rapidity, and in the same logical harmony, as with the doctrinal

\footnotetext{
147.

2 JaCques Lambert, Les Year Books de Langue Francaise (1928) 132-
} 
teaching by lectures. But the effort made to discover them will fix them more deeply in his mind, and give him a more exact idea of their meaning and their nuances.

The educational value of the student's personal effort towards learning can only be had insofar as the results, to which the study of cases should lead, are not unveiled in advance by the explanations of a lecturer, or by the consultation of lav treatises. The teacher's guidance must remain discreet; he must limit himself to choosing, as a theme for discussion, the cases best adapted to make the historical development of the law understood, and to bring the student, by the so-called Socratic method, to define for himself the present status of the law. Hence the two pedagogical postulates which express the proper individuality of the American case method: discussion of cases without lectures, and casebooks without treatises.

This rigorism, which is hard to carry through to the end even in the universities of the United States, has without doubt contributed to hinder the expansion of legal education by the study of cases outside of its natal ground. In an articie which appeared in 1913 in the Journal of the Society of Comparative Legislation, ${ }^{3}$ the dean of the law school of the University of Melbourne, Harrison Moore, after having seen the method at work at Columbia and at Harvard, advised against its adoption by the Australian universit'es. Moreover, it has not succeeded, up to these latter years, in gaining access to the Canadian provinces of common law. Even at the present moment it seems that it is not used very much outside of Ontario and Nova Scotia, although it may be used in a few subjects. This may result, as is suggested by A. Z. Reed, from the comparatively recent origin of the law schools, from their instability, from the small number of students who can be counted upon to purchase casebools when published, and, above all, from the almost complete absence of full-time teachers, who alone are prepared to do effective teaching by the study of cases. In reality the case method is a very slow teaching method. This is what a distinguished French jurist, Robert Valeur, establishes in a very well documented book, ${ }^{5}$ which represents the fruits of two years' study in American universities. The investigation which Valeur made in the United States shows ${ }^{6}$ that, in spite of the limitation of the student's field of work by a system of election between different topics, the activity of the teacher using the case method is largely

\footnotetext{
3 Moore, Legal Education in the United States (1913) 13 J. Soc. Cosip. LEG. AND INT. LAW 207 (No. 28).

* REED, op. cit. supra note 1 , at 324 .

5 Valeur, L'Enseignenient dU Droit ex France et aux Etats-Usis (1928).

${ }^{6}$ Ibid. 240 et seq.
} 
absorbed by the very great number of hours of work which this method imposes on him.

During the course of these last four or five years the teaching of law by the study of cases and casebooks has begun to spread into Canada by the medium of the two law schools which, by their relative age and degree of organization, stand in the foreground in the common law Provinces of Canada: Dalhousie University at Halifax and Osgoode Hall at Toronto. In both of these schools the instructors have recently adapted the study of cases to the particular conditions of the local law by selecting Canadian cases and employing them in draft form, mimeographed or multigraphed. But only at Osgoode Hall have printed books resulted from this work of adaptation.

Falconbridge's work is the first casebook printed in Canada. It also states that it is the first of a series of casebooks for use in Canadian law schools which will include all the law subjects which are deemed suitable for the study by the discussion of cases. This set, which does not have a general editor, will celtainly include works from Dalhousie and perhaps from other law schools. But the strategical advantage conferred on Osgoode Hall by the relatively large number of its students and teacher's makes it probable that the majority of the books of this series will be prepared at Toronto. The second volume, which appeared at the end of 1928,7 is by one of the teachers of this school.

These publications are the announcement, not of a future or probable adoption in English-speaking Canada of the American casebook as it has been worked up by Harvard, but the development, in this common meeting ground of American and English university influences, of a new conception of the case method, a conception at once more supple, more nuanced, and above all more tolerant. We may justly call this conception the Canadian case method.

The purposes of this pedagogical movement have been thus expressed by Falconbridge in a report addressed in April, 1928 to the Legal Education Committee of the Ontarian Law Society:

"The term 'case-method' is, of course, merely a general term, and the use of the method varies with every lecturer and every subject. The method is unsuitable to some subjects, and in fact in the majority of subjects it is not used at the law school. It should be regarded as a flexible method, to be used with due regard to all the circumstances. It should perhaps be applied in a progressive manner and, for example, be accompanied in the early stages of a student's course by more explanation on the lecturer's part than is necessary or desirable in later stages."

7 Smith, Cases on the Laiv of Trusts (1928). 
The following explanations have been furnished me by Falconbridge's letters: At Osgoode Hall the case method is used exclusively in the following subjects: contracts, torts, personal property, sale of goods, trusts, agency and partnership, wills and administration of estates, equity, conflict of laws. The case method is not at present used at Osgoode Hall in the following subjects: history of English law, jurisprudence, real property, company laws, bills and notes, criminal law and procedure, civil procedure, mortgages, constitutional law, evidence, and bankruptcy-in some of these because the method is not considered suitable or sufficient and in others because there are no suitable Canadian printed or mimeographed casebooks.

The Canadian case method thus differs from the American method in rejecting the pretensions of an integral monopoly of legal education. It differs also in admitting the aid given by the study of the works of legal doctrine even in those fields for which it claims the principal exploitation.

The characteristic features which bring us to look upon this casebook as inaugurating a Canadian case method are the following:

(1) The author is not satisfied merely to group, in each of the paragraphs, the decisions which shed light on the meaning and significance of one or several of the sections of the Sale of Goods Act. Each group of decisions, tied together by the illustration of a section of the English Act, is followed by annotations. These are measures which are natural-no matter what may be the conception which one holds of the role of the case method-in a casebook given to a codified branch of the law. Nor is this either absolutely irreconcilable with the strict American conception of the case method. For Langdell himself terminated his first casebook by a dogmatic résumé of the law of contracts. And some of his disciples, such as Ames and Scott, have placed copious footnotes under the decisions reported.s But that which takes us the farthest from the Langdell traditions is the care taken in the annotations to refer to the pages of the latest editions of two English treatises-Benjamin on Sales and Chalmers on The Sale of Goods-where the principles in play in the decisions of the paragraph are explained; and also the references to Halsbury's Laws of England and the particularly frequent footnotes referring to law review monographs, such as the Lave Quarterly Review, the numbers of which have been very attentively analyzed. What is the role of this scientific and critical bibliography of doctrinal works on each subject if it is not to permit the best among the students to prepare themselves for the discussion of

\footnotetext{
${ }^{8}$ VALEUR, op. cit. supra note 5 , at 200.
} 
the chosen cases by consulting all the essential writings on the matter? For the casebooks without treatises are substituted casebooks illuminated by the light of legal doctrine.

(2) Falconbridge himself indicates in his preface that his casebook differs from Williston's in that he has not attempted to give so full a collection of the older English cases, but that he has included many Canadian and recent English cases. And, in reality, out of 172 printed cases, 84 are prior to and 88 subsequent to 1900 in date; 100 are English and 49 Canadian. ${ }^{9}$ And, among the 20th century cases, the most numerous belong to the second and, above all, the third decade of this century. The large place given to recent English decisions is without doubt due, in a certain measure, to the fact that the political unity of the British Empire, and the supervision of the Privy Council, has maintained a solidarity between modern English and Canadian law, while the political separation relaxes each day a bit more the ties which connected American and English case law. But these political facts do not explain the elimination of many well known old cases decided prior to the codification of the law, and their replacement by cases taken from the judiciary production of the years nearest to 1928. Falconbridge has doubtlessly thought, and I agree with him, that texts of legal history should not be presented outs:de of the environment of the social, political, and economic institutions which gave them birth, and that it is correct to leave the teaching of history to historians, who alone can make of it an instrument for the understanding of the life and the evolution of law. Thus he refers, at the beginning or end of each of his paragraphs, to chapters of the monumental work, Holdsworth's History of English Law, and sometimes also to the work of Pollock and Maitland, as well as to other English historical works. This constitutes a new affirmation of the necessity for the case method to appeal to the aid of all the didactical branches of legal literature.

(3) While the American casebooks, except for a few happy exceptions, only seek to show the unity of the common law as developed in the United States, as national American law, the first Canadian printed casebook takes, as its experimental laboratory, a subject where the uniformity of the codified laws has practically been realized, thanks, on the one hand, to the diffusion of the essential provisions of the English Sale of Goods Act in the British Dominions, and notably in all the Canad:an Provinces except Quebec, and, on the other hand, thanks to the imitation of this statute by the draft of the Uniform Sales Act of 1906 which, twenty years after its drawing up, had already

${ }^{9}$ Cf. Book Review (1928) 6 CAN. B. Rev. 173. 
penetrated, although sometimes modified, into the statute books of 28 American states. And Falconbridge has talken up this field of study in the spirit of a Commissioner on the Uniformity of Legislation. This spirit is shown, not only by the percentage given to recent English cases, but also by the use of Australian decisions. It shows itself also by the reproduction in the notes, which close each paragraph, of the texts of the American Uniform Sales Act, each time that they show fundamental divergencies in comparison with the English Sale of Goods Act. If the author does not give the American decisions, it is probably in order not to double the size and cost of his publication. And also probably because, when the first attempts at the adaptation of the case method in Canada were made, Williston's casebook was introduced at Dalhousie, and from there came to be used at Osgoode Hall. Nevertheless, Falconbridge, in the bibliographies which close his paragraphs, cites the corresponding chapters of Williston's great treatise on Sales with the same regularity as those of the English treatises. This is sufficient to open the entire horizon of common law to the students.

I regret-it is the only criticism which I have to make-that he does not bring the students to crass the horizon of common law, by placing before them some judicial decisions of the Province of Quebec, taken among those where the civil law and the common law show points of opposition. He does not give any of these, and rarely refers to the Civil Code of Lower Canada. Only one citation of this code struck me." It is not probable that there are many others, perhaps not even any. This is a gap which he will necessarily be brought to fill in the subsequent editions of his book, since his advocacy of uniformity of legislation in Canada should make him feel very strongly the disadvantages of these contrasts in legal education. The efforts of his associates in the struggle to make the provincial laws harmonious, between themselves, in those chapters where business feels the most imperious need for it, has struck the resistance of the lawyers of Lowrer Canada. This resistance can be overcome only by an appeal to the critical spirit and to the spirit of conciliation of the two groups in an effort to bring together the two legal traditions by the progressive elimination of their technicalities and survivals.

This is the path indicated by Falconbridge in a paper read before the Canadian Bar Association in 1927.12 After having recalled that the Conference of Commissioners on Uniformity of

10 FALCONBRIDGE, op. cit. supra note 1, at 616, referring to $\S \S 1543,1998-9$ on the rights of the unpaid seller.

${ }^{11}$ Falconbridge, Desirable Changes in the Common Law (1927) 5 CAN. B. REV: 581 . 
Legislation in Canada had, in the year 1920, prepared an act to repeal the hard and unjust rule of common law which refused to recognize the legitimation of children by the subsequent marriage of their parents, and obtained, between 1920 and 1922, the adoption of this law in the Provinces of common law; after having enumerated other occasions upon which prominent English speaking lawyers had advocated the change of the common law rules so as to bring them to approach the civil law rules, he suggested the desirability of the repeal or the reform of some clauses of the Sale of Goods Act which are less adapted to the actual needs of business than those of the Civil Code. He did this in the hope, which does not appear to have been realized, of inducing his colleagues from Quebec to adopt a less jealous attitude with regard to anything savouring of uniformity of law, and to invite them to submit to criticism of their principles of civil law. A few isolated moves by men of the scientific advance guard in both camps would not be sufficient to produce the desired result in spite of the facilities offered by the community of descent of medieval merchant law which unites common law and civil law in commercial matters. ${ }^{12}$ In order to attain this result it is necessary to have, on both sides of the legal frontier, a common enlarging of the methods of legal education which will force the new generations of lawyers to weigh the merits and defects of the competing rules of the civil law. and the common law concerning the sale of goods and the similar parts of merchant or industrial law. And this permanent comparison can hardly be realized, in an efficient fashion, except by the use of casebooks, written in the English and French languages, and which present, side by side, the most characteristic of the recent decisions handed down on each great problem of law in the two spheres of rival culture.

And yet for this it is necessary that the study of cases and the production of casebooks spread into the law schools of the countries of civil law. But is this possible? Is it a probable eventuality? Is there, for example, a chance that casebooks can acclimate themselves in French-speaking Canada, either directly, or by taking the European route and coming into Canada as a French or Latin exportation? This is a problem which has particularly struck the attention of A. Z. Reed, for he devotes to it, in his study, the first chapter of the Canadian part of the Carnegie Foundation's investigation. First he confirms the impression which the examination of Falconbridge's casebook gives us - the inaptitude of the American method of legal education to apply integrally to the English speaking provinces of Canada. He states:

12 Cf. Faiconbridge, Banking and Bills of Exchange (4th ed. 1929) 15. 
"The case method is not merely in an earlier stage of development in Canada than in the United States. There is little apparent prospect of its ever being developed to the extreme exemplified in many American schools. Notably, it is not likely to result, as with us, in disintegrating the curriculum. In our leading law schools, the elective system [a brealing up of the body of the law in membra disjecta among which the student choses a limited number of examination subjects] has been an apparently inevitable consequence of the attempt to cultivate, by this time-taking method, the entire field of technical law. The obvious pedagogic weaknesses of this system of education have generally been regarded as more than counterbalanced by its advantages; and, at least in the past, American legal scholars have probably been justified in taking this position. Their Canadian colleagues, however, show no disposition to follow their lead in this respect. No Canadian law school now operates under the elective system, and none of the plans for future development contemplate its introduction." 13

The desire to furnish, at least during the early stages of study, in the curriculum which undergraduates are made to follow, an initiation to all the essential parts of the system of law is also deeply ingrained in the European university law schools; and this example tends to reinforce the Canadian resistances on this point. But this is only an obstacle to the acceptance of the specifically American case method, but not of the Canadian case method which, by limiting the use of casebooks to some subjects, the number of which may be proportioned to the conditions and the duration of the course of instruction, is easy to conciliate, and in fact conciliates itself at Osgoode Hall, with a presentation of the enserible of the body of the law.

A. Z. Reed, although a stranger to the legal profession and to the teaching personnel of the law faculties, has given proof of a very wide-awake sense of legal realities, in the pages where he examines "the special problem created by the cnclave of French civil law in Quebec." "In discussing the real causes of the opposition of the lawyers of Lower Canada to any possible use of the case method, he has brought out the weak points of the explanation which is habitually given. The point of departure of this current explanation is to be found in a fact, often noted, and which Redlich's investigation ${ }^{15}$ brought out: that of the influence exercised on the birth and the propagation of the Langdellian method by "the particular conditions in which the American law finds itself, as unwritten law, in its present stage of development" It is not doubtful that the extraordinary suc-

$33 \mathrm{REED}$, op. cit. supra note 1 , at 327 .

14 Ibid. 328 et seq.

is Rejulch, The Comimon LaW and the Case Mietrod in Auremican UNIVERSTY LAW SCHools (1914) 35, constituting Bulletin 8 of the Carnegie Foundation for the Advancement of Teaching. 
cess obtained in the United States by Langdell's invention has been principally due to the fact that it appears "as a return to the principles of legal teaching demanded by the nature itself of the common law," ${ }^{16}$ that is to say, by its judiciary origin. This character of the law made, found, or elaborated by the judges is, in effect, much more marked in American than in English law. For the control of the constitutionality of the statutes assures the American courts of justice the last word in the conflicts which arise between them and the legislatures, while the rulings of the English courts may be overruled or repealed by the acts of Parliament. And the possession of constitutional control gives them, in the United States, a freedom of conduct which the English courts do not enjoy. One must therefore recognize the profound exactitude of the words of one of the most resolute adversaries of the Harvard Law School's process of legal education, Dean Simeon E. Baldwin:

"Never in any country has it been possible to apply this new method of teaching except in Great Britain, in the United States, and their dependencies ... and in a sense the United States offers a more favorable ground than England for a practical use of Professor Langdell's theory." 17

But this conclusion, which in reality is only exact as to the application of the particular type of the case method propagated. by Harvard, is apt to lead one to be drawn on a logical, but slippery descent, and to conclude that the case method is, in general, unsuitable for adoption by countries, like France or the Province of Quebec, where the codes take the place that the loi judiciaire or common law occupies in the United States, and in which the systeme juridique is made up of principles, and not of rulings of cases of law. This is a conclusion which is much too affirmative, because it does not establish the necessary distinctions between the several forms of the case method-a conclusion which, from the present, reveals itself as rash and erroneous.

That the case method and its instrument of application, the casebook, are not necessarily tied to a regime in which the unwritten law is predominant, that they may function in a very satisfactory manner when applied to the study of written law, is what Falconbridge seems to have shown experimentally-and before him others like Williston-by taking, for the framework of the introductory volume of a series of casebooks, a codified branch of the law for which the codification has been pushed

16 Ibid. 37.

${ }^{17}$ Cf. VATEUR, op. cit. supra note 5, at 206. 
further in its details in Canada or the United States than in any civil law country.

One may reply, it is true, to this objection, that neither the English Sale of Goods Act, nor the Canadian acts which reproduce it, nor the American Uniform Sales Act, are truly pieces of codification; they are, in reality, but the written stabilization of pre-existing judicial customs. Their authors have, in general, abstained from any reconsideration or reformation of the principles of the law of sales. They were satisfied to cast aside, among the rulings of anterior decisions, those which gave but bad law, or which only prevailed in a minority of jurisdictions in the United States, and to sanction those which appeared to be good law or as solutions already prevailing. Thereafter it is quite natural that the work of the casebook authors proves particularly fruitful in a field where the statute law has only intervened with a view of consolidating, aiding, and putting in order the production of case law. And one hastens to add that it would not be the same with those branches of the law which have been the object of a true codification, that is to say, of a reconstitution of the ensemble of their principles by a legislator substituting for anterior customs the rules which appeared to him as more suitable to the exigencies of the present time.

Thus one finally becomes inclined to justify a permanent and necessary attitude of reluctance on the part of the civil law schools towards the case method by saying: this method-an instrument for the study of the case law-could not live in countries which ignore the rule of stare decisis and refuse to count the judicial decisions as forming one of the sources of the law. Such is the case of French law and the law of the Province of Quebec, which for this cause will always remain impervious to the benefits of the case method.

A. Z. Reed puts his finger on the weak spot of this reasoning by showing that, if the judicial decisions do not constitute, in the theoretical structure of the civil law, a foundation of the law, case law is, nevertheless, in fact an important part of the law as it is practically applied. He writes:

"Not merely is it true that detailed statutory provisions must be construed or interpreted by the judges under any system of law. In addition, the genius of the civil law seems to lend itself more readily than ours to the expression of broad general principles in statutory form. That portion of their law, for instance, which corresponds to our law of Torts, is grounded in a single brief provision of the code; the many detailed rules that flow from this vague principle are determined, as with us, by judicial opinion." 18

18 REED, op. cit. supra note 1 , at 329. 
The learned author exaggerates and simplifies a bit when he says that the French law of delits civils flows from a single provision of the Civil Code; it flows from five sections (articles 1382 to 1386) the contents of which have been developed and retouched by a few contemporary statutes. But it cannot be contested that this law of delits civils, which is just as full as the English law of torts, has been developed likewise in its essential parts by the play of the case law. Neither is it doubtful that large and important chapters-outside of the law of non-maritime insurance, which is the most frequently cited example-have been introduced into the French law principally through the action of the courts.

In this regard the true realities of civil law have been still more clearly felt and defined by an American specialist of law reporting, the editor-in-chief of the National Reporter System, William L. West, who, in a circular addressed to the subscribers of his reporters, explained in these terms the disconcerting discoveries made during a period of study in Berlin:

"In the United States there is a very current impression that, in the countries where the written law prevails, all the legal controversies are settled by reference to the codes. . . . A A least as far as Germany is concerned, I think that this is a quite mistaken impression. ... In these later years the courts have been called on to decide a growing number of cases in which the codes were of little assistance.... There is a great deal of law actually applied which can only be found in the decisions of the courts.... During these last ten years there has in fact been a startling development of what is sometimes called in America judge-made law."

This development of judge-made law, under the name of jurisprudence, is still more accentuated in a country, like France, where the codification dates from the beginning of the 19th century, than in Germany where the national codification of the civil law (Burgerliches Recht) was only brought about between 1896-1900.

I cannot reproduce too often the preceding lines of the distinguished American law reporter, and I hope that they will contribute to dissipate the erroneous views on the present functioning of the system of civil law which have been spread-on the strength of a conception of the codification which has been for a long time out of date-in the ensemble of the English speaking world. One finds them expounded in one of the best English books on the general theory of the sources of law which have appeared in these later years, C. K. Allen's Law in the Making. I willingly subscribe to the opinion of this book held by Jacques Lambert, who sees in it "the most fruitful effort made, up to the present time, towards the reconstitution of the 
processes of formation of the English theory of the case and of the legal authority of precedents." 19 But the chapters given to the history of continental law and, above all, to the contemporary mechanism of the formation of French law, are not as solid as those given to English law.

It was with astonishment that I read these lines in Allen's book, lines which are hard for a reader living under the ernpire of the French law to grasp:

"Justinian's non exemplis sed legibus judicandum est [the exclusion of mos judiciorum] might be taken as the epitome of the deductive principle of judicial reasoning, widely accepted at the present day on the Continent. We may take French law as characteristic.... An extremely important part is played by extra-judicial and extra-legislative doctrine. The great commentaries on the Civil Code are scarcely less authoritative than the Code itself. ... Without extra-judicial doctrine, there would be no doctrine at all." 20

Nevertheless the author finds that the Dalloz and Sirey standard collections of decisions are just as indispensable to French lawyers as the law reports are to their English colleagues. But he thus explains-it is this part of his exposition which is the most surprising for a Frenchman-the role of the recucils de jurispmidence:

"But here again we find a fusion, strange to the English lawyer, of judicial and extra-judicial doctrine.... The judgment takes a form singularly jejune to one who is accustomed to the full, reasoned judgments of English Courts. The facts are given in bare outline, and the judgment states little else than the main facts and the statutory provisions upon which the decision is based. It is left to the reader to fill up many gaps in the reasoning which brought the case within those provisions-not always an easy task. But, if the case is important, a reasoned exposition of the judgment, with abundant references to other decisions, is often added. This gloss, however, comes not from the Court itself, but from some accredited jurisconsult. ... The total effect of this union of decision and interpretation is not unlike an English report. There is, however, the great difference that all English judgments are motivés, whereas it is only a small minority of French decisions which have the advantage of a learned commentary." 21

Among the features of C. K. Allen's description, there are some which were partially exact diring the part of the 19th century, such as, for instance, the authority which the extrajudicial doctrine had claimed for itself, but which remained theo-

19 LAMTBERT, op. cit. supra note 2 , at 76-7.

20 ALLEN, LAW IN THE MAKING (1927) 117-9.

21 Ibid. 119-20. 
retical, because the usage of the courts (la jurisprudence) never was willing to recognize it, and which the law writers have, for about forty years now, ceased to demand. There are others, however, which have never existed, even during the time nearest that of the codification. If the rationes decidendi are presented with much more brevity in the arrets francais-in those of the Cour de Cassation above all-than in the judgments of the English courts, it does not necessarily mean that they are not ordinarily motivés. On the contrary, the abscnce or the insufficiency of the motifs is for every French judgment a decisive ground for cassation. Not only should the motives of each of our judicial decisions be sought in the body itself of the arrat, but the criticism or approval developed in the annotations of the Sirey or the Dalloz are neither the substitutes for, nor the complements of, these motifs. These notes have no more authority than those given on the English or American decisions in the Law Quarterly Revicu, or in the Harvard Law Revicw and Yale Law Journal. The doctrine which, alongside of the provisions of the codes and statutes, serves as the effective basis for the administration of justice is not, as C. K. Allen thinks, the doctrine of the law schools and of the legal writings. No, it is, just as in England and the United States, the doctrine established by the previous judicial dicta of the courts.

It is the same with the case law as with the case method. It may present itself, and effectively it does so, in diverse forms. There is a specifically English variety of case law, which owes its originality to the progressive establishment, by a quasi-constitutional custom, of a mechanism of regulated production of judicial law. But there also exists, in the civil law sphere, and notably in France, a more common variety of the case law, the production of which is only regulated by the spontaneous play of sociological laws which control the life of the law.

The French case law differs from the English or American case law in the following characteristics: Its authority is only de facto and not de jure. In France there is no room for the English distinction between the higher courts, whose opinions go to constitute judge-made law, and the lower courts, which are powerless to create binding precedent. All the courts, without exception, take part in the elaboration of jurisprudence; and the decisions of the modest justices of the peace and courts of first instance have the honour of being reproduced in the recucils d'arrêts and of being quoted in court, although their influence is in proportion to the position in the judicial hierarchy of the tribunal taking the decision invoked as precedent. In France, the judicial precedent does not, ipso facto, bind either the tribunals which established it nor the lower courts; and the Court of Cassation itself retains the right to go back on its own decisions. 
The courts of appeal may oppose a doctrine proclaimed by the Court of Cassation, and this opposition has sometimes led to a change of opinion on the part of the higher court. The practice of the courts does not become a source of the law until it is definitely fixed by the repetition of precedents which are in agreement on a single point. The very fact that in France the authority of legal precedents is only a de facto authority means that they are more difficult to establish than in England. Mioreover they are less stable; the Supreme Court itself may spontaneously reverse its own practice and substitute another. The birth and death of judicial rulings cannot be dated with the same precision as in England, because, in most cases, they are only the progressive outcome of a chain of decisions. It is only after the event that the "decision of principle," the decision, namely, which leads to the creating or fixing of a judicial precedent, can be distinguished in the series. But France has just as many leading cases as England.22

The cases in which the total abstention of the legislature leaves a free field to the judiciary production of legal rules are less numerous in France than in England, but in return the French judiciary enjoys much greater freedom in the interpretation of legislation. In the English view of the functions of judicial interpretation, the courts are required to keep to the letter of the law, while in France the judge is instructed to seek for the very spirit of the law so that this may prevail. And the general tendency is to consider the provisions of the statutes as needing to be construed in the light of the "spirit of the law" in general-and not in that of a particular act-as it is at the moment when the act is to be applied, and not as it was when the act was passed. The French judiciary has never shown so much independence of the written law as that displayed by the American courts of justice; but it has often given proof of more independence than the English judiciary.

From these facts it is clear that it is not the character of the codified laws of the systems of laws studied in the universities of the civil law countries which has rendered them impermeable to the specifically American variety of the study of law by the case method. And the fact itself that Harvard's method has not succeeded in gaining entrance to the country where the English type of case law was born confirms the fact that it is necessary to seek elsewhere the causes of this impermeability. They are without doubt manifold. But the deepest, the most durable, is the irreconcilability of the Langdellian system of legal education with the evolution which, for some time now, tends to transform

${ }^{22}$ Cf. E. Lambert, Pic and Garraud, The Sources and Interprelation of Labour Law in France (1926) 14 INT. LAB. REv. 1. 
the continental law faculties into mixed schools of social science and of law, and to obtain from them, for the law students, a general culture appropriate to their professional tasks, more than an immediate preparation for practice, preparation which cannot be fully acquired save in the office of a practitioner. ${ }^{23}$ The curriculum of the French faculties of law is today composed of approximately equal parts of instruction in economics, legal history, and social science and of instruction whtch prepares more immediately for the practice of the legal profession. The general culture courses can be usefully given only in the form of rapid syntheses of the last état of scientific research. Further, the time allowed renders it necessary to present them in the form of oral lectures. The necessities of competition oblige, and will always oblige, the purely professional instruction to seek the same goals of prompt and comprehensive initiation to the present conclusions of their branch of learning.

But when the case method consents to cooperate with didactic instruction, and to become its loyal auxiliary, it can easily take root in the field of the civil law. The fact that the first casebook published in England, to be used to experiment with the case method at Cambridge, Finch's Cases on Contract, was re-edited, in association with Mr. R. T. Wright, by Professor W. W. Buckland, a jurisconsult destined to become one of the greatest authorities of the world in the science of Roman law, and whom several continental universities are honored to count among their doctors honoris causa, caused this eventuality to be anticipated ever since 1896. Since this time the case method has become effectively acclimated to several civil law countries. Among them, and neglecting the precedents marked in Germany, Egypt, and elsewhere by collections of "juridical problems," I will cite only the examples of France, Holland, and Portugal.

From Holland comes to me the third edition, dated 1928, of a volume of select Dutch cases, rendered very usable by its moderate dimensions and by the classification of the decisions under the articles of the Dutch Civil Code: Arresten over Burgerlijh Recht, by $\mathrm{H}$. R. Hoeting with a preface by Professor E. M. Meijers. Like that of Falconbridge, this casebook is the chief book of a series which already includes the following volumes: Arresten over Handelsrecht, Arresten over Intermationaal Privatrecht, Arresten over Staatsrecht, Arresten over Strafrecht. The collection of casebooks of Mr. Hoeting and his collaborators aspires, it is clear, to cover all the essential branches of Dutch legal education.

In France, a volume of Espèces Choisies Empmentées à la

\footnotetext{
${ }^{23}$ See Lambert, L'Enseignement du Drott Compare comme Science SOCIALE ET COMME SCIENCE INTERNationale (1928).
} 
Jurisprudence has been published in Paris by the Dalloz publishing house, in a first edition, 1924, and in a second edition, reviewed and augmented, in 1927. This book was prepared by a group of professors of the law faculties working under the direction of Henri Capitant. It differs both from the old collections of legal problems, because it only employs cases actually taken from the law reports, and from the true casebooks, because it only gives the analysis of the facts and the position of the problems of each case, in order not to influence the student's efforts towards a solution by an anticipated knowledge of the judge's decision. But in the last part, which constitutes a sort of teachers' book, it indicates the place occupied in the law reports by each of the cases employed. It contains two prefaces, one written by Capitant, the other by me, showing the merits of a third case method, which is now added to the American and Canadian methods, the French case method, and which we consider as the first and most indispensable of the tools of the French Salle de Travail. If Capitant asked me to join this enterprise, it is because he wanted to place in his collection a few cases taken from English and American case law.

The third case method, however, has only attained its full development in the Portuguese universities, where it was definitely introduced following an investigation, carried on by the University of Coimbra, on the several methods of legal education employed in the old and new worlds. Much space was given to a study of the results of the case method at Harvard in the conclusions of this investigation, which were included in an official report, approved by the Law Faculty of Coimbra MTarch 27, 1911, and published by the University in French under the title, Projet de réforme des études de la Faculté de Droit.

In accordance with these conclusions the laws organizing the Faculties of Law-published in the Diário do Govcrno on January 12, 1923 and October 27, 1928-have made it obligatory to divide each of the essential courses of the Portuguese law schools into both lectures and seminars organized under the case method plan, and have sanctioned, by examination questions, both methods of teaching. But, although this Latin case method was used at Coimbra and Lisbon for about ten years prior to its generalization by these legislative texts, it has not yet resulted in any printed casebooks.

It is as a student of comparative law, as founder of the oldest university Institute of Comparative Law, that I was asked to preface an American selection of cases ${ }^{28}$ and a French Recucil

2s Albertsworth, Cases oN Industrial LAW (1928). This book is compiled from the point of view of comparative jurisprudence, recognizing the interdependence of the legal manifestations of modern industrial society. For a review of this book see (1929) 38 Y ALE L. J. 699. 
d'Espèces Choisies. And it is for the same reasons that I am today asked to review the volumes-modeles of a Canadian and a Dutch series of casebooks. This shows that the authors of these works feel the necessity of working for the sake of the international science of law at the same time as for the sake of the national or provincial legal education. They are tracing the way for selections of cases in which the comparative direction, collaterally begun in the casebooks of Capitant, Falconbridge, and Albertsworth, will become the principal goal and the raison d'être of publications themselves. The science of comparative law-or international private law in the literal sense of the term -has for the moment a greater need for international casebooks than for treatises on comparative law. Thirty years' experience in the teaching of comparative law leads me to the conclusion that, in this branch of legal education, the case method should be employed in the Canadian form-such as it is at Osgoode Hall-and not in the French form. This instruction is destined for post-graduate students or for advanced undergraduates, who already have knowledge of the general anatomy of one of the national systems of law, and thereafter can be usefully trained in the deeper study of some special topics of the universal learning of law.

Institutes of comparative law have increased since the war in both French and German universities. Some persevering in-dividuals are tending to bring them into some Italian universities in spite of the opposition, irreducible up to the present time, of the Roman law specialists who fear the competition of a more modern discipline. The attraction of these new organs of juridical teaching is beginning to be felt also in the New World. For, from time to time, I receive from various countries of Latin America requests for information on the working conditions of an Institute of Comparative Law. So I am happy to take advantage of the opportunity, which is here offered me, to complete and render more precise my replies to these requests for information.

In an Institute of Comparative Law lectures are necessary in order to teach the students the particularities of the present sources of the law-statute law, judge-made law, extra-judicial practice or Rechtstatsachen, administrative application of the law-in the key-systems of law, such as the English, French, and German laws; to explain to them the purposes of comparative law; and to describe for them the proper methods of comparative jurisprudence and the influence which the relations of the law with the other social sciences exercises upon them. The general notions thus obtained must then be illustrated and controlled, by studying, by the case method, each year, one or 
another of the special subjects which, by their character, form natural experimental laboratories of comparative jurisprudence.

My experience is in accord with that of Falconbridge at Osgoode Hall in recognizing that the branch of the law in which the work of international unification has been pushed the furthest up to the present time-the negotiable instruments law-is badly adapted, by reason of the regulative character of its provisions, to an exclusive use of the case method. The two branches of law which have always struck me as the most suitable for the development, by the case method, of the student's understanding of comparative jurisprudence are, in the first place, labor law; the first seed of industrial law, which takes its spirit of universality from the International Labour Office, one of the results of the Treaty of Versailles; and in the second place, and better. yet, the law of the sale of goods, the nucleus of the law of commercial transactions and markets.

The Institutes of Comparative Law already possess the necessary casebook for the teaching of the first of these. This is due to the International Labour Office, which, following a desire which I expressed in the Bulletin of the French Societe de Leirislation Comparée, Les Débuts du Law Reporting International, has, since 1926, regularly published an International Survey on Legal Decisions of Labour Law, which each year gives, in the three key languages of international contacts-English, French, and German-a selection of decisions of interest to comparative jurisprudence handed down by the courts of justice of the countries possessing the most highly developed case laws. The analysis of cases of international scientific interest has been limited, for the reviews of 1925 and 1926, to Germany, England, France, and Italy. But beginning in 1927, the review will be extended to include the United States, and probably in 1928, Spain. For my part I hope that it will not extend any further. The selection of the decisions to be reported or analyzed is left, for each country, to the responsibility of a jurist of that country.s Hovever, under the auspices of the International Labour Office, the various national collaborators in this work have knitted warm and durable lines of cooperation among themselves. The three volumes of this collection which have already appeared have furnished me with the necessary casebook for the guidance of my students in the study of the iurisprudcince intermationale du traveil; a casebook which has the double advantage of being kept up to date each year and of giving the cases studied both in the lan-

${ }^{25}$ In England H. C. Gutteridge, a doctor honoris crusa of the Univer ity of Lyons, who $I$ am accustomed to find as English shareholder in the international enterprises for the development of comparative law. 
guage of my students and that of the country in which the decisions have been handed down.

An international selection of cases on commercial sale, established by the same methods, revised and edited in the principal key languages of social science, would not be of less utility for the teaching of comparative law by the case method. The necessity for this is still more pressing, because the law of commercial sale is a better field of application for the comparative method than labor law. While the latter is a battle ground of antagonistic forces which the peace-making activities of the International Labour Office do not always succeed in conciliating, the former, on the other hand, is directed toward international uniformity by the combined efforts of trade associations. An investigation made by my Japanese collaborator, Dr. Masaichiro Ishizaki, on one of the most highly organized industries-that of raw silk-and which is analyzed in volumes 17,18 and 19 , of the Bibliothèque de l'Institut de Droit Comparé de Lyon, shows us the development, in this commercial branch, of the very detailed rules and regulations for the sale of the merchandise of this trade, which spread themselves into the codifications of trade practices of the principal international markets of the silk trade; which impose their guiding principles on commercial arbitration; and which gain an international value through their use in the common forms of contracts of national or local associ-. ations of the raw silk trade. These legal and economic phenomena, which are also apparent in other industries, are the products of a growing commercial standardization and, hence, are destined to become even more marked as the progress of this standardization advances. This indicates that, if the jurists do not take the lead in this advance towards the "internationalization" of the law, the advance will continue without them and against them, as the aggressive appearance of the latest conquests of commercial arbitration already appear to show; such as the New York Arbitration Law of $1920^{26}$ and the United States Arbitration Act of 1925.27 The Instituto Internazionale per l'Unificazione del diritto Privato, recently opened at Rome, and other international organizations, should be particularly well equipped to supply the teachers of law with the tools needed in order to carry out their social duty.

International casebooks on this subject, and on others particularly adapted to study from the universalistic point of view, are indispensable to students of comparative law in order to prepare for the realization of the programme outlined by Rudolf von Jhering. In his Geist des Römischen Rechts, this great juris-

20 N. Y. Cons. LAwS (Cahill 1923) c. 2.

2743 Stat. 883 (1925), 9 U. S. C. (1926). 
consult and legal historian writes, referring to the national and provincial systems of law of his day:

"Science has degraded itself into jurisprudence of states; the scientific frontiers coincide, in the jurisprudence, with political frontiers. Discouraging, unworthy, form for a science! However, it rests upon itself alone to assure for all future times, in another form, that of a comparative jurisprudence, the universal character which it possessed for so long a time." ${ }_{2 B}$

If glossators, postglossators and humanists were able, during centuries, to assure to the largest part of continental Europe the benefits of a large community of law, they owed it to the existence of the Corpus Juris Civilis, which permitted them to work on the materials of a single code. In order to provoke the reawakening, so ardently desired by Jhering, of the spirit of humanism in the science of law, it will be necessary that other organizations of juridical international cooperation compete with their older brother and model, the International Labour Office, in the furnishing, to students of comparative law, of all the countries of civil law as well as those of common law, of international textbcoks and particularly international casebooks indispensable to a scientific and common action.

281 Von JHering, Geist des RöMrschen Rechts (5th ed. 1894) 15. 